\title{
What is The Envisioned Future of Azerbaijan Companies? The Case of Chamber of Commerce and Industry
}

\author{
Sumeyra Alpaslan Danisman \\ Mevlana University, Konya, Turkey \\ Ayse Kocabacak \\ Mevlana University, Konya, Turkey
}

\section{Introduction}

Azerbaijan which is referred to as "land of fire" has s geopolitical location at the crossroad between Europe and Asia. The Azerbaijan has a small, open but fast growing economy (Hölscher, 2012). Azerbaijan is the most stable country in regards to economic and politic conditions in Caucasus. The existence of rich natural resources, educated human resources and being on a crucial area increase the possibility of brilliant future of Azerbaijan Republic (Zengin, 2010). One of the strategic advantages of Azerbaijan is being located on a vital transport and energy corridor in a globalized network of capital, goods and services in between Europe and Asia (Baranick and Salayeva, 2005). The mentioned situation of Azerbaijan economy results in attracting more investments (Zengin, 2010). Companies in Azerbaijan, similar to other developing economies' organizations, have a significant role in supporting establishment of new economy in the transition period. Moving aboard, being global and building desirable future can be accomplished by strategic visions. In order to discuss future of Azerbaijan economy, this paper has been aimed to investigate vision statements of Azerbaijan companies and underline most frequently expressed issues. Main characteristics of transition economy, transformation of Azerbaijan and the role of organizational vision on strategic objectives have been discussed in the first part of theoretical section. In the second part, main question of the research and methodological settings are structured in order to investigate Azerbaijan companies' visions. After determining most frequented issues in vision statements, each of them has been investigated in details. 


\section{Theoretical Background}

\section{Azerbaijan Economy in Transition Period}

Economic transition equals to privatization, liberalization and stabilization (Hölscher, 2009). The concept of transition economy is defined as the transition process from the central planned economy to a market economy (Guneyet al.2011). The termtransition economy is used to define countries which own socialist economic system, at the same time, try to build market economy. Poverty, underdeveloped infrastructure, a strong and strict authority and large and coarse public sector and bureaucracy can be the mutual problems of transition economies (Altay, 2003). While transition process of all economies face the difficult task of building new market institution; the speed, success and period of reforms generally vary greatly across countries (Beck and Laeven, 2005).

Acanturk and Arslaner (2013) underline the need of central Asian economies to integrate with global economy. In order to achieve national development and improvement in economics, these countries should continue the reforms on foreign capital and privatization. Azerbaijan became an independent state in October 1991. After independency, The Azerbaijan authorities began its stabilization program in 1995 which was smoother in some other transition economies. In addition, the privatization process followed stabilization program in 1996 (Singh and Laurila, 1999). The government of Azerbaijan accomplished the privatization of more than 29.000 small, 1.500 medium-sized businesses by the end of 2001. In addition, the privatization of large companies has occurred more slowly than others (Baranick and Salayeva, 2005).

However, the transition of Azerbaijan economy is not limited to the general definition of transition process. In Azerbaijan, transition started firstly with radical changes in social life then followed with transition from totalitarian regime to democracy, public initiatives to private entrepreneurship, communal approach to individuality, from planned economy to the efforts to integrate into globalizing world economy (Guneyet al., 2011). Azerbaijan registered strong macroeconomic performance in between 2010-2013. To achieve the economic objective for continuing development strategy, Azerbaijan needs to address the following transition challenges such as improving business environment, integrating into the global economy, deepening financial intermediation and advancing public infrastructure reform (The European Bank, 2010).

\section{Vision Statements as Indicators of Envisioned Future of Azerbaijan Economy}

According to the study of Chun and Davies (2001), companies are generally positioning themselves on the Internet by including mission and vision statements within their websites. Vision statement has been a very popular topic in some business issues such as leadership, strategy and organizational change (Levin, 
2000). A vision statement is defined by Berson and his colleagues (2001) as an inspirational message to followers which includes optimistic expressions about the future, confidence in achieving positive future challenges and opportunities, while underlining the intrinsic needs and connecting to the core values of organizations. Kantabutra and Avery (2010) found that effective visions include main characteristics such as conciseness, clarity, abstractness, stability, future orientation, challenge and desirability or ability to inspire.

Core ideology and envisioned future of company are the two major components of a well-conceived vision. Core ideology means/refers to what we stand for and the purposeof our existence. Envisioned future defines what we aspire to become, achieve andcreate (Collins and Porras). It was claimed by Nanus (1992) that a right vision is not only an image of a desirable future but also an actor towards progressing to future by mobilizing people into action towards achieving it. Vision statements are used in a various ways and mean different things to different people. But effective visions can describe the future of company more attractively than the present (Levin, 2000). One of the main functions of vision is to help people make smart choices. While goals are accomplished, the answer to the question "what is next" becomes clearer. On the other hand, vision is important for leaders because leadership means going somewhere inherently. It can be possible for leaders to focus on the needs of people, when the vision is clarified and shared (Blanchard and Stoner, 2004).

As a vision study done in Turkey, Sabuncuoğlu\&Gök (2008) researched about Turkey's top 500 companies' mission and/or vision statements which include common expressions summarized as "to meet customer expectations with producing high quality product/services by effective production methods and to be a leader organization in its own sector". In addition, Kasowski and Filion (2010) found out that only 154 of 500 firms (Fortune 500, 2005) have clearly-identified vision statements and only $37 \%$ of these vision statements include essential elements of a vision such as being specific, realizable, involving change, looking towards future and identifying a market place. The study of Ay and Koca (2012) on ISO 500 companies of Turkey draws the attentions to most frequently highlighted issues in the vision statements such as "leadership, innovation, globalization, growth and development, leading (proactive movement), quality, social responsibility and economic efficiency". In the context of mentioned researches, we have focused on frequently highlighted issues of the clearly identified vision statements of Azerbaijan companies. 


\section{Research: What is The Envisioned Future of Azerbaijan Companies?}

\section{Method and Setting}

The main research is based on an exploration of the main dynamics of envisioned future of Azerbaijan companies. The term envisioned future refers to the official vision statements of the companies. Hence, the sample of the research is selected from member list of Azerbaijan Republic Chamber of Commerce and Industry (Azerbaijan Republic CCI or the Chamber) which is an independent, nongovernmental, nonprofit public organization. The Azerbaijan Republic Chamber is an organization which performs its activities with the enterprises, corporations, businessmen and their associations (ARCCI, 2013). The current study was conducted during the first half of 2013. Data collection and analysis of the research had been completed by the end of May 2013. It is structured with qualitative methodology to investigate vision statements of businesses. The visions of the companies were reached from their official websites. The data collection method comprised of document investigation (Bailey, 1982) and obtained data was analyzed with content analyzing method (Holsti, 1969; Luborsky, 1994). After applying content analyzing method, two researchers checked and compared results of qualitative and quantitative data.

\section{Findings}

Number of the members Azerbaijan Chamber was 141. While investigating their official websites, it was detected that 27 of 141 companies had clearly identified vision statements on their websites. 36 members did not have any vision statements in the corporative information section of the websites. 68 member's websites could not be reached. 10 members had vision statements but because of being global companies, the vision statements were not related with Azerbaijan's future.

Figure 1: Percentage of Including Vision Statement

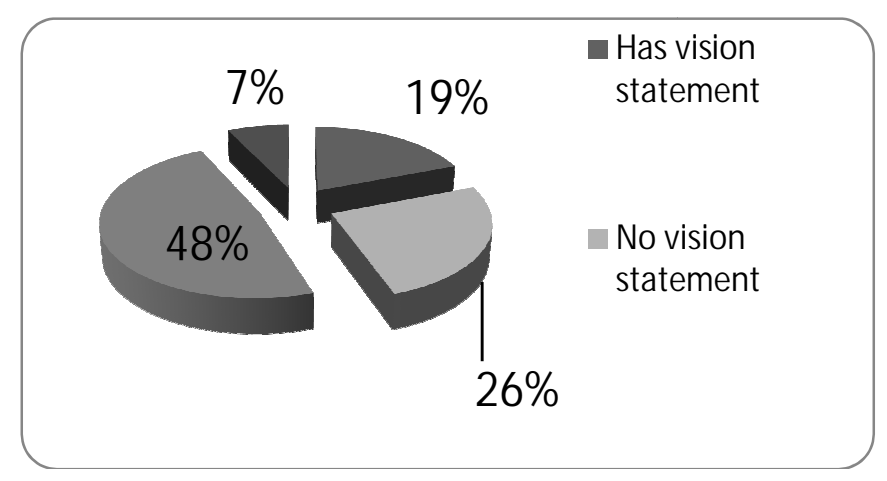


In this research, content analysis method was used to examine vision statements of Azerbaijan Chamber's members and most frequented words and phrases have been determined. According to findings, development, internationalism, values, responsibility, quality, strategy and teaming are the most frequented words in vision statements. They are followed by the words of creativeness, competition and profit.

Table 1: The concepts most frequently highlighted in the vision statements

\begin{tabular}{ll}
\hline Concepts in Vision Statements & Frequency \\
\hline & \\
Development/ improvement & 59 \\
International/Global & 33 \\
Values & 28 \\
Responsibility & 24 \\
Quality & 24 \\
Strategy & 21 \\
Team-orientation & 18 \\
Innovation-Creativeness & 15 \\
Competition & 13 \\
\end{tabular}

After determining most frequented words in vision statements, each of them were investigated in details. The first and most frequented word is development/ improvement which highlight three main issues. As a first issue, development of human resource management includes advanced system of human resource management, theoretical and practical development of human resources, new forms and methods of training, rotation of the material and moral motivation system, developing the personnel permanent improvement, empowerment of employees regularly and increasing of human resource potential. Developing and diversifying Azerbaijan economy, long-term sustainability, sustainable development and development policy for Azerbaijan future, fostering the economic development, contributes to the socio-economic development, taking important and leading role in development of Azerbaijan, helping development of Azerbaijan on the world stage and supporting entrepreneurship and regional development are expressed in the context of economic vision. Developing skills and expertise of business management, improving available terms regarding services, continuous research and development activities and creating innovative and valuable solutions are underlined related with business vision. For instance, one of the sample organizations focuses the role and importance of human resource development in its own vision statement.

"We aim to achieve the highest banking standards, in particular with respect to efficiency, transparency, customer satisfaction, responsibility, prudence and human resource development." 
Table 2: Development/Improvement

\section{Human Resource Management Vision}

Advanced system of human resource management

Theoretical and practical development of human resources

New forms and methods of training, rotation, of the material and moral motivation system

Develop the personnel permanent improvement

Empowerment of employees regularly

Increasing the HR potential

\section{Economic Vision}

Develop and diversify AZ economy

Long-term sustainability

Sustainable development

Development policy for Azerbaijan Future

Fostering the economic development of Azerbaijan

Contribution to the socio-economic development

Taking important and leading role in development in Azerbaijan

Help Azerbaijan develop on the world stage

Support to entrepreneurship and regional development

\section{Business Vision}

Develop and apply focus-appropriate skills and expertise to a wide array of business management

Improvement of available services' terms

Continuous research and development activities

Creating innovative and valuable solutions

The second most frequently used word is internationalism in vision statements. Emphasized issues of internationalism are related to macro economy, management, marketing and production. Expanding the notion of "made in AZ", maintaining the positive image of the companies internationally, being a global player and respecting international standards are stated as internationally marketing issues. Developing Azerbaijan on the world stage is the vision of economic goals of the companies. Conducting business everywhere in the world and strengthening business internationally are expressed in order to underline importance of globally organizational structuring. Producing with international standard proves the highquality production vision of the Azerbaijan companies. As an example, one of the clearly identified vision statements includes the internationally oriented aim of Azerbaijan companies. 
"Our vision is to become a vertically integrated international energy company resting upon advanced experience on operation efficiency, social and environmental responsibility."

Table 3:International/Global

International/Global Vision

Expand the notion of "Made in AZ" beyond boundaries

Strives to maintain the positive image in the international arena

Helps Azerbaijan develop on the world stage

Conduct our business everywhere in the world with the highest standards

Strengthen business ties with the local and international structures

Respecting the international production standards

To be a global player

Organizational culture as a popular discussion area of management is one of the most important parameter to influence people in organization and their relations with exterior and interior. It is not only the set of shared values, norms, symbols, systems and beliefs but also the way of how to behave, plan, act and complete. Hence, while Azerbaijan companies mention the envisioned future of the organizations in vision statements, they also describe the cultural values of companies in future. Responsibility, transparency and professionalism are the most frequented ones in vision statements. After that determination, reliability, effectiveness, following the path of excellence, ethics and morality, loyalty, efficiency, flexibility, cooperation and universal human values are the part of envisioned future of Azerbaijan companies. For example, it is possible to see two of organizational values in the vision statements below.

"We aim the presence of a team, making efficient decisions, with high moral values and professionalism, working in an environment of mutual support and team spirit through the introduction of new forms and methods of training, rotation, of the material and moral motivation system to achieve high level of service..."

Responsibility is one of the other expressed issues in vision statements. Azerbaijan companies plan their future in context to social and environmental responsibility. With social responsibility, they underline the importance of corporative, strategic, socially-oriented and problem solving responsibility for their society in future. Other responsibility is based on environmental perspective. Producing, serving, managing, distributing and performing business practices with environmental care and paying attention to ecological issues are as important as business objectives for Azerbaijan companies. Hence, they construct their future on the responsibility for society and environment. For instance, one of the sample organizations expresses their special attention on building corporate social responsibility policy. 
Table 4: Values as a Dynamic of Organizational Culture

\title{
Values in Visions
}

\author{
Responsibility \\ Transparency \\ Professionalism \\ Determination \\ Reliability \\ Effectiveness \\ Follow the path of excellence \\ Ethical and moral values \\ Loyalty to work \\ Efficient and flexible organization \\ Cooperation with stakeholders \\ Universal human values
}

"We pay special attention to corporate social responsibility in terms of development of products, services and their delivery to end users. We possess necessary financial resources for solution of social problems."

Table 5: Responsibility

Social Responsibility Vision

Corporate social responsibility

Social responsibility strategy

Socially-oriented company

Improving the well-being of local communities

Invest in and create opportunities for our people

Solving social problems

Continuously increase added value to the Society

\section{Environmental Responsibility Vision}

Environmental protection

Care for the environment

Attention on ecological balance during business practices

Environmental responsibility

Quality as a most frequented word in vision statements aimed by Azerbaijan companies, while applyingto important areas such as business practice and production. Increasing the quality by benchmarking is underlined in vision statements as an objective. On the other hand high quality execution, business quality and being the brand of quality are expressed phrases in visions as business targets of Azerbaijan companies. In addition, quality in production and services are 
the other underlined statements. Maximizing, improving and establishing, developing and presenting quality in products and services aimed by Azerbaijan companies to accomplish high quality standards. One of the companies' visions includes aiming and performing best quality in production and service.

"Our vision: The company, which provides best quality of service in Information and Communication Technology sector in Azerbaijan and its region; Professional support in development, execution and implementation of IT projects; Taking important and leading role in development of ICT sector in Azerbaijan Republic."

Table 6: Quality

\section{Business Quality Vision}

Benchmarks in quality

High quality execution of business objectives

Business quality of the modern international standards

Make "Made in AZ" the symbol of quality

Best quality of service and production

\section{Production/Service Quality Vision}

Maximize the value and quality of our products/services

Improve the quality of products/services

Establish unique products

Develop and present new products/services

Present best products/services

Qualitative service and output of products

Improvement of available services' terms

Development of new products and services

Being team oriented is envisioned by Azerbaijan companies. The importance of teamwork is underlined by aiming to have motivated, developed, improved and professional teams. On the other hand, cooperation and well-structured connection among the team members and key players of inside and outside is the other expressed objective of Azerbaijan companies. For instance, one of the vision statements indicates creating strong connection between the world and organizational team members.

"We will create relevant connection between the world and our team members that means, we will obtain maximum possible information by not damaging commercial interests of the bank and not violating the principle of confidentiality."

Innovation and creativeness are the key words frequented in vision statements as a source of new applications. Producing creative and innovative solutions, 
supporting innovative thoughts, innovative objectives, creating advanced systems and aiming creative purposes are stated objectives in vision statements of Azerbaijan companies. They plan to have a capability of conceiving original thoughts and implementation of new things. In the vision statement below, it is emphasized for creating innovative solutions and services.

Table 7: Team-orientation

\section{Teaming Vision}

Having a motivated and developed team

Improvement team spirit

Professional team

Motivation and development of teams

Increased connection between the world and our teams

Cooperation with team members and business partners

"Our vision is creating innovative IT solutions and provides IT enabled services to delight customers worldwide and build relationships based on Trust, Values and Professionalism."

Table 8: Innovation and Creativeness

\begin{tabular}{l}
\hline Vision Based on Innovation and Cre \\
Creating innovative IT solutions \\
Supporting innovative thoughts \\
Technological innovation objectives \\
Creation of advanced systems \\
Aiming creative purposes
\end{tabular}

Competition word is expressed in vision statements with some features such as being fair and strong. It is possible to say Azerbaijan companies aim to increase quality by competition. Hence, they underline improvement of human resources by competition at all levels, high qualitative competitive production systems, competitiveness and sustainability in companies' growing processes. In a vision statement, the importance of personnel competition is highlighted in order to provide permanent improvement at all levels.

"Our activity is directed to the permanent improvement of personnel competition on all levels, extension of clients list and achievement of high professionalism in all related spheres. Projects implemented by our company can be considered as exemplariness for the companies working in construction and engineering sphere." 
Table 9: Competition

\section{Competition Vision}

Improvement of personnel competition all levels

High-qualitative competitive production

Competitive and sustainable growth

Strong and fair competition

\section{Conclusion and Discussion}

As a country in transition in the process of economy being converted from central planned economic system to free market, Azerbaijan experiences radical changes. In order to achieve economic objectives, the role of private entrepreneurs is increasing. Azerbaijan companies need to have strategic goals in order to support development process. By accomplishing strategic goals, it can be possible for companies to reach their own envisioned future which is defined by what they aspire to become, achieve and create (Collins and Porras, 1996). Vision, an optimistic expression about future (Berson et al., 2001), is one of the strategic stars -interdependent elements - of a strong corporation brand and it is as important as culture and image (Hatch and Schultz, 2001). The main question in this study is related to vision statements of Azerbaijan companies. According to findings, Azerbaijan companies structure their future on developmental, international, teamoriented, responsible, innovative and competitive strategies; value and quality based objectives. They aim to develop and have improvement on human resource management, national economy and business vision. Hereby, in addition to economy and business visions, they underline the impact of human resource on organizational objectives. Converting Azerbaijan companies to global players can be possible with international strategies. Hence, being international/global is emphasized in vision statements as a part of Azerbaijan's future.

Building a corporate culture as one of the strategic stars supports the corporate vision. Azerbaijan companies desire to possess the values such as responsibility, transparency, professionalism, determination, reliability, effectiveness, excellence, ethics, morality, loyalty, efficiency, flexibility, universal values to have a stronger culture which supports the vision of organizations. Social and environmental responsibility of Azerbaijan companies indicates their sensitivity to social needs, problems and ecological issues. Some of them specifically underline the importance of environmental protection and express it in vision statements. Highly qualified production and services can be accepted as a first step of reaching international standards and being a global brand. Therefore, maximizing and improving quality is one of the most important aspects which are expressed several times in vision of Azerbaijan companies. Converting human resources to motivated and professional teams, supports increasing highly qualified production and services. The importance of innovation and creativeness is underlined in vision 
statements as benefitting the life of customers and finding more efficient solutions. Having an innovative and creative corporate mind encourages companies to reach objectives easily. The crucial function of strong and fair competitiveness is underlined in vision statements to develop national economy and improve social conditions. For that reason, Azerbaijan companies aims to create competitiveness in order to support growing process.

In conclusion, the main contributions of this study are examining the existence of clearly-identified vision of Azerbaijan companies and focused subjects in these statements. Vision statements are the most effective way of companies to position themselves on the internet (Chun and Davies, 2001) and include inspirational messages (Berson et al., 2001) concerning future of these organizations. The crucial role of the vision statements should be comprehended by practitioners and researchers. Practitioners can use vision statements to reflect their organizations to followers and researchers can do more research on vision statements to read and understand organizations well. As a problem on vision statements, some of organizations choose to copy some vision statements mentioned by others and it causes an unreal and fake similarity between companies' future plans. Therefore accuracy, reflectance and reality of the vision statements are extremely important for the future of companies. In this context, the main aim of the current research is to attract the attention of practitioners and researchers to the role of vision statements to achieve strategic goals for envisioned future.

For future studies, it is suggested to evaluate effectiveness and efficiency of vision statement as a strategic element for Azerbaijan companies. Comprehending the crucial role of vision statements will provide organizations to reflect themselves well and researchers can conduct more contributable researches on organizations. Moreover, vision statements can be investigated and compared from different characteristics of Azerbaijan companies such as size, industry and performance. It will provide more specific examination about Azerbaijan companies' future directions on different contexts. If the quality and quantity of the researches based on vision statements are increased, more effective and reflective visions which include conciseness, clarity, abstractness, stability, future orientation, challenge and desirability or ability to inspire (Kantabutra and Avery, 2010) will be created by organizations.

\section{ACKNOWLEDGEMENT}

This study is the improved and revised version of a paper which was presented in the First International Economics and Law Symposium organized by Mevlana (Rumi) University on13-14 June 2013. 


\section{References and notes:}

ACARTURK, E. ve H. Arslaner (2013), “Geçiş Ülkelerinde Devletin Ekonomik Rolü Yabancı Sermaye ve Özelleştirme",

www.econturk.org/Turkiyeekonomisi/ ertugrulhakan.doc.

ALTAY, A. (2003), Geçiş Ekonomilerinde Devletin Ekonomik Rolleri, Görevleri ve Kobilerin Durumu, Maliye Araştırma Merkezi Konferansları, Maliye Araştırma Merkezi Yayın No:86, Kırk birinci Seri-Y1l 2002, İstanbul.

ARCCI (2013), http://www.chamber.az/page.html?id node=297

AY, Ü. ve A. İ.Koca (2012), "ISO 500 listesindekiIsşletmelerinMisyon, VizyonveDeğerlerinin İçerik Analizi”, Organizasyon ve YönetimBilimleriDergisi, Cilt 4, Say1 2, 2012 ISSN: 1309-8039 (Online), 201-210, http://www.sobiad.org/eJOURNALS/dergi_YBD/arsiv/2012_2/unal_ay.pdf

BAILEY, K. D. (1982). Methods Of SocialResearch(2nd ed.). New York: FreePress.

BARANICK, M. J. and R.Salayeva (2005), "State-Building in a TransitionPeriod: The Case of Azerbaijan, TheCornwallisGroup X: Analysis for New andEmergingSocietalConflicts",

http://www.thecornwallisgroup.org/pdf/CX 2005 12-Baranick2-CX-July17.pdf.

BECK, T. and L.Laeven (2005), "InstitutionBuildingandGrowth in TransitionEconomies", Policy Research Working Papers, July, ISSN: 1813-9450.

BERSON, Y., B. Shamir, B. J. Avolioand M.Popper (2001), "TheRelationshipBetweenVisionStrenght, Leadership Style andContext", TheLeadershipQuarterly, 12, 53-73.

BLANCHARD, K.andJ.Stoner (2004), "TheVisionThing: WithoutItYouwillnever be a World-Class Organization", LeadertoLeader, Winter.

CHUN, R. and G. Davies (2001), "The Role of Mission and Vision Statements in Positioning Strategy", The Journal of Brand Management, vol 8(4), May, 315-333, PalgraveMacmillan.

COLLINS, J. C. and J. I. Porras (1996), BuildingYourCompany'sVision, Harvard Business Review, September-October.

EUROPEAN BANK(2010), "Strategy for Azerbaijan”, Document of The European Bank for Reconstruction and Development, http://www.ebrd.com/downloads/country/strategy/azerbaijan_2010.pdf.

GUNEY, A., I. Sabirogluand C. Bulut (2011), "What Kind of CapitalismforAzerbaijan? A Comparative Analysis From Economic View", 2011 New Orleans International Academic Conference, New Orleans, Lausiana USA.

HATCH, M.JandM. Schultz(2001), "Arethe Strategic Stars Alignedfor Your Corparate Brand", Harward Business Review, 79/2 (February): 128-134.

HOLSTI, O. R. (1969), Content Analysis For The Social Sciences and Humanities, Menlo Park,Addison-Wesley, CA.

HÖLSCHER, J. (2009), "20 Years of EconomicTransition: SuccessesandFailures, TheInstitute of EconomicResearch", Kyoto University (KIER) http://www.euij-tc.org/news/events_2007/20090223/Holscher.pdf.

HÖLSCHER, J. (2012), “Azarbaijan in Transition”, IaiWorkingPapers, 12-20 July, ISSN 2280-4331. http://www.chamber.az/index en.html

KANTRABUTRA, S. \& G. C. Avery(2010), “ThePower Of Vision: StatementsThatResonate",Journal of Business Strategy, 31(1), 37-45. 
KASOWSKI, B. and L. J.Filion (2010), "A Study of the 2005 Fortune 500 Vision Statements", Working paper no: 2010-04, April, ISSN : 0840-853X.

LEVIN, I. M. (2000), "VisionRevisited, TellingtheStory of theFuture", theJournal of AppliesBehavioral Science, 36(1), March, 91-107.

NANUS, B. (1992), VisionaryLeadership: Creating a Compelling Sense of Direction for Your Organization, San Fransisco, Jossey-Bass Publisher.

SABUNCUOĞLU, A. ve O.Gök (2008), "Büyükİşletmelerin Web SitelerindeYer Alan Misyonve Vizyon İfadelerininPazarOdaklılıkAçısındanİncelenmesi”, AfyonKocatepe Üniversitesi, İI..B.F. Dergisi, C.X ,S I, 123-141.

SINGH, R. and J.Laurila (1999), “Azerbaijan: Recent Economic Developments and Policy Issues in Sustainability of Growth”, BOFIT Discussion Papers, No 5, Bank of Finland, Institute for Economies in Transition.

ZENGIN, Eyüp (2010), Piyasa Ekonomisine Geçiş Sürecinde Azerbaycan, İstanbul TicaretOdasıYayınları, Yayın no: 2010-59, İstanbul.

\title{
SUMMARY
}

\section{What is The Envisioned Future of Azerbaijan Companies? The Case of Chamber of Commerce and Industry}

\author{
Sumeyra Alpaslan Danisman \\ Mevlana University, Konya, Turkey \\ Ayse Kocabacak \\ Mevlana University, Konya, Turkey
}

Central Asian Countries which are in transition movement are converting from a centrally planned economy to free markets. The mentioned transition from communism to capitalism causes the economies to remove trade barriers, to support private business and entrepreneurs. Azerbaijan has become one of the rapidly developing economies after gaining independence in 1991. The transformation of Azerbaijan has attracted the interest of investors and caused high economic growth in the last decade. The current condition in Azerbaijan draws the attention of the researcher to investigate the vision of companies in Azerbaijan. The objective of the research is to explore the main dynamics of the envisioned future of these companies. This study is structured as a qualitative research. The sample consists of 141 members of Azerbaijan Republic Chamber of Commerce and Industry as a case of Azerbaijan. The vision statements of the companies have been reached from their official websites and investigated with content analyzing method. According to the results of the research, only 27 of 141 companies have provided clearly-identified vision statements and these statements indicate modern managerial issues such as development/improvement, international/global, values, responsibility, quality, strategy, team-orientation, innovation-creativeness and competition.

Key words: Transition economy, Azerbaijan, envisioned future, vision statement 